\title{
Blood group as a prognostic indicator in breast cancer
}

\author{
P J HOLDSWORTH, J THOROGOOD, E A BENSON, A D CLAYDEN
}

\begin{abstract}
A retrospective analysis of 1001 patients with invasive breast cancer showed a difference in survival between patients with different blood groups. Analysis of time from operation to local recurrence and to general recurrence reinforced this finding. The difference between blood groups became increasingly significant after accepted prognostic factors were allowed for. Patients at particularly high risk of early death or general recurrence were those with blood groups $B$ and $A B$, those with group AB having a greater relative local recurrence rate.
\end{abstract}

\section{Introduction}

Several factors are known to influence survival of women with breast cancer, ${ }^{1}$ but little is known of the prognostic influence of different blood groups. In a series of 1323 radical mastectomies for cancer carried out from 1940 to 1965 Donegan associated 10 year survival with various constitutional, clinical, and pathological factors, and analysis of the blood groups of 986 patients showed that a good survival was associated with blood group AB (10 year relative survival $66.2 \%$ ) and a poor survival with blood group B (10 year relative survival $27 \%$ ). ${ }^{2}$ We present a similar sized series and compare the results.

\section{Patients and methods}

Between 1976 and 1981 in a study of prognostic factors in breast cancer the Yorkshire Breast Cancer Group collected 1186 cases of operable, invasive breast cancer $\left(T_{0}-T_{3}, N_{0}-N_{1 B}, M_{0}\right)$; information about blood groups was available for 1001 of these. The remaining

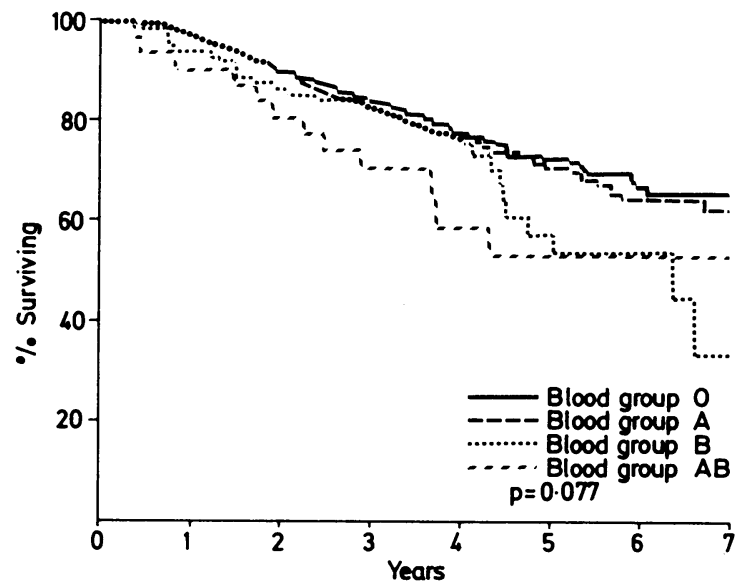

FIG 1-Survival of patients with breast cancer according to blood group.
TABLE II-Log rank survival analysis of patients with breast cancer

\begin{tabular}{|c|c|c|c|c|c|c|}
\hline $\begin{array}{l}\text { Blood } \\
\text { group }\end{array}$ & $\begin{array}{c}\text { No of } \\
\text { patients }\end{array}$ & $\begin{array}{c}\text { No of } \\
\text { deaths } \\
\text { observed }\end{array}$ & $\begin{array}{c}\text { No of } \\
\text { deaths } \\
\text { expected }\end{array}$ & $\begin{array}{c}\text { Relative } \\
\text { death } \\
\text { rate }\end{array}$ & $\begin{array}{c}\text { Relative } \\
\text { general } \\
\text { recurrence } \\
\text { rate }\end{array}$ & $\begin{array}{c}\text { Relative } \\
\text { local } \\
\text { recurrence } \\
\text { rate }\end{array}$ \\
\hline $\begin{array}{c}\mathrm{O} \\
\mathrm{A} \\
\mathrm{B} \\
\mathrm{AB}\end{array}$ & $\begin{array}{r}485 \\
403 \\
82 \\
31\end{array}$ & $\begin{array}{r}120 \\
106 \\
27 \\
12\end{array}$ & $\begin{array}{r}130.69 \\
107.29 \\
19.97 \\
7.05\end{array}$ & $\begin{array}{l}0.92 \\
0.99 \\
1.35 \\
1.70\end{array}$ & $\begin{array}{l}0.93 \\
0.98 \\
1.27 \\
1.80\end{array}$ & $\begin{array}{l}0 \cdot 87 \\
1.05 \\
1 \cdot 14 \\
2 \cdot 10\end{array}$ \\
\hline $\begin{array}{l}\text { Total } \\
\text { p }\end{array}$ & 1001 & 265 & & 0.077 & 0.077 & 0.038 \\
\hline
\end{tabular}

General Infirmary at Leeds, Leeds LS1 3EX

P J HOLDSWORTH, FRCSED, surgical registrar, department of urology E A BENSON, MA, FRCS, consultant surgeon

Yorkshire Regional Cancer Organisation, Cookridge Hospital, Leeds LS16 6QB

J THOROGOOD, BSC, data processor

Department of Community Medicine, University of Leeds, Leeds LS2 9JT

A D CLAYDEN, PHD, senior lecturer in medical statistics

Correspondence to: Mr P J Holdsworth.
185 cases were not included because certain data were missing. The numbers of patients available for analysis at the time of operation and one, two, and five years later were $1001,966,883$, and 259 , respectively. These were not survival figures but reflect the fact that only a proportion of the patients had undergone the follow up at five years. The standard treatment used was simple mastectomy and usually radiotherapy if axillary nodes were affected.

\section{Results}

The distribution of particular blood groups in the population of women presenting with operable breast cancer was not significantly different from that of women in the areas of Yorkshire covered by the contributing surgeons $\left(\chi^{2}=1.98 ; p=0.57\right)$ (table $\left.I\right)^{3}$

Log rank analysis ${ }^{4}$ showed a difference in survival between patients with different blood groups. Patients with blood groups B and AB had higher relative rates of death and general recurrence than those with groups $\mathbf{O}$ and $\mathbf{A}$ when analysed as four separate groups (table II, figs 1 and 2), but the differences just failed to reach significance $(p=0.077)$. A significant result was, however, observed when the time to local recurrence was analysed $(p=0.038)$ (fig 3 ), and in this case patients with group $\mathrm{AB}$ alone had a high relative local recurrence rate. When the high risk groups, $B$ and $A B$, were combined and compared with the combined low risk groups, $O$ and $A$, a significant difference in survival $(p=0.015)$ and general recurrence $(p=0.023)$ was seen (figs 4 and 5 ). This combination of groups increased the 


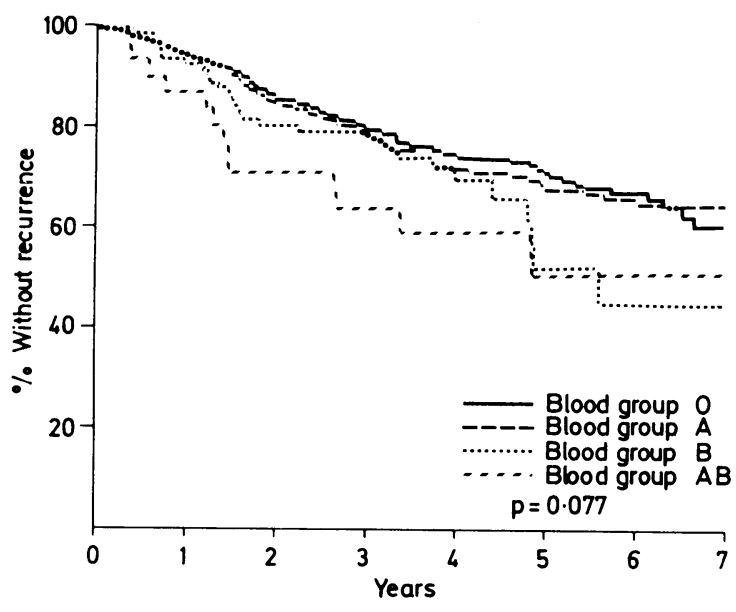

FIG 2-Rate of general recurrence of breast cancer according to blood group.

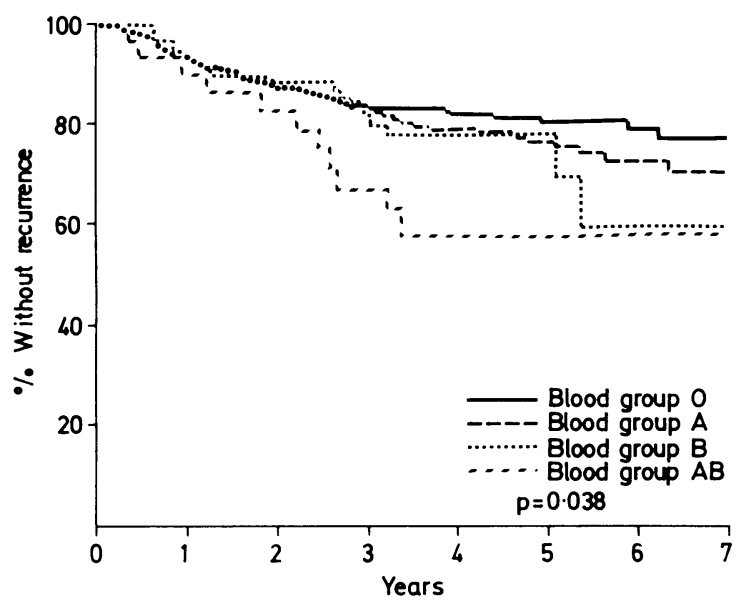

FIG 3-Survival without local recurrence in patients with breast cancer according to blood group.

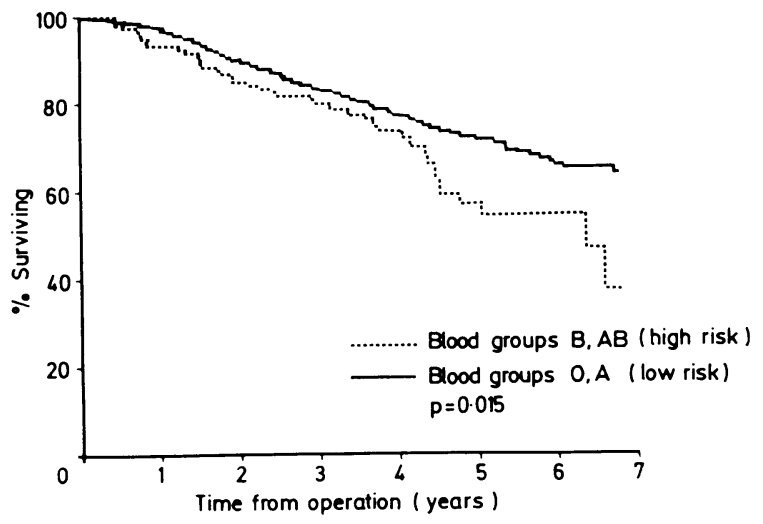

FIG 4-Survival of patients with breast cancer with high risk and low risk blood groups.

p value for the analysis of time to local recurrence to 0.063 (fig 6). Thus the type of blood group may have a different effect in an analysis of time to local recurrence (in which patients with group $\mathrm{AB}$ were at particularly high risk) than in an analysis of time to general recurrence or death (in which those with groups $B$ and $A B$ had high relative rates of death and general recurrence). To see whether established prognostic factors ${ }^{1}$ accounted for the difference in survival we analysed the results allowing for individual factors such as TNM stage, clinical stage, etc (table III). Rhesus factor was also included because of its relation to blood groups. By taking these factors into account we ensured that the overall difference between blood groups was not biased by the presence of a particular factor. All results remained significant, and most increased in significance, when these prognostic factors were allowed for individually. The relative risk ${ }^{5}$ of patients having $\mathrm{B}$ or $\mathrm{AB}$ blood group in all cases lay between $1 \cdot 5: 1$ and $1 \cdot 8: 1$.

To examine the influence of more than two prognostic factors simultaneously we used Cox's regression model ${ }^{5}$ on the established key prognostic factors, $T$ stage, $M$ stage, clinical stage, pathological grade, and pathological nodal invasion. This tested whether blood group could make any useful contribution to a model of survival, and a stepwise analysis was used to identify a set of independent variables that were significantly related to survival. $\mathrm{T}$ stage, $\mathrm{N}$ stage, and blood group were found to enter the model, and the contribution of blood group was significant $(p=0.013)$ with a relative risk of 1.57 ( $95 \%$ confidence interval $1 \cdot 12-2 \cdot 21$. The pathological factors grade and nodal invasion, together with blood group, all entered the model, and blood group again made a significant contribution $(\mathrm{p}=0.025)$

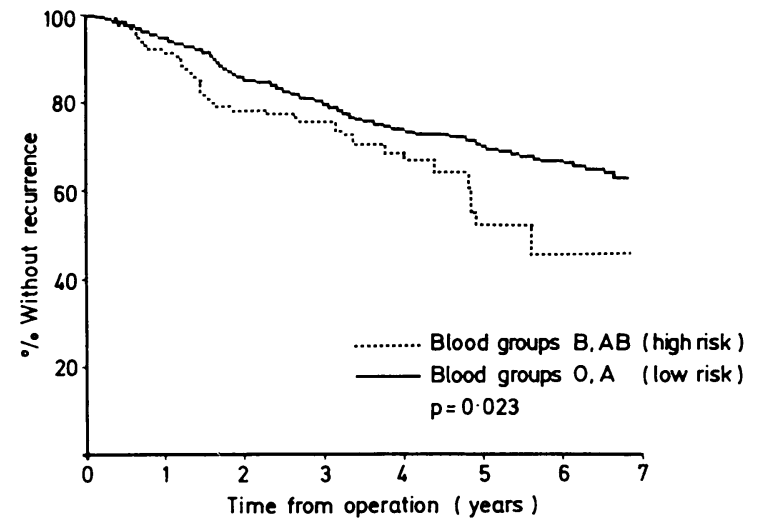

FIG 5-Survival without general recurrence in patients with breast cancer with high risk and low risk blood groups.

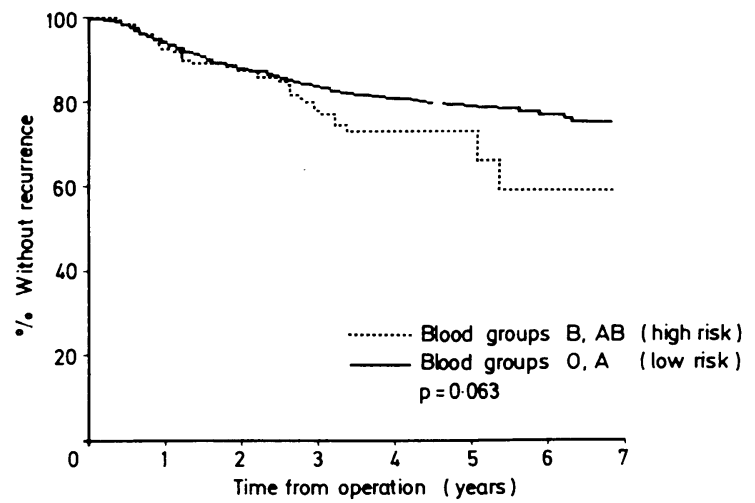

FIG 6-Survival without local recurrence in patients with breast cancer with high risk and low risk blood groups.

TABLE III-Results of analysis controlling for effect of blood group and other prognostic factors on relative risk of death of patients with breast cancer

\begin{tabular}{|c|c|c|}
\hline Factor allowed for & $\begin{array}{l}\text { Relative risk } \\
\text { (95\% confidence limits) }\end{array}$ & p Value \\
\hline \multicolumn{3}{|l|}{$\begin{array}{l}\text { Blood group } \\
\text { Blood group and: }\end{array}$} \\
\hline $\begin{array}{l}\text { Blood group and: } \\
\text { Palpable axillary nodes }\end{array}$ & & \\
\hline $\begin{array}{l}\text { Palpable axillary nodes } \\
\text { Cancerous axillary nodes }\end{array}$ & $1.60(1 \cdot 13-2 \cdot 28)$ & 0.008 \\
\hline T stage & $1.64(1 \cdot 17-2 \cdot 31)$ & 0.004 \\
\hline $\mathrm{N}$ stage & $1.51(1.08-2 \cdot 12)$ & 0.017 \\
\hline Clinical stage & $1.63(1 \cdot 16-2 \cdot 30)$ & 0.004 \\
\hline Pathological size of lump & $1 \cdot 62(1 \cdot 14-2 \cdot 31)$ & 0.007 \\
\hline First grade & $1.51(1 \cdot 06-2 \cdot 15)$ & 0.022 \\
\hline Grade assessed at one centre & $1.64(1 \cdot 16-2 \cdot 33)$ & 0.005 \\
\hline Tubules & $1.67(1 \cdot 13-2 \cdot 46)$ & 0.010 \\
\hline Pleomorphism & $1.79(1.21-2.65)$ & 0.003 \\
\hline Mitotic activity & $1.72(1 \cdot 16-2 \cdot 55)$ & 0.006 \\
\hline Nodes invaded & $1.47(1.02-2 \cdot 10)$ & 0.036 \\
\hline$T$ stage and $M$ stage & $1.57(1 \cdot 12-2 \cdot 21)$ & 0.013 \\
\hline Grade and nodes invaded & $1.56(1.08-2 \cdot 27)$ & 0.025 \\
\hline $\begin{array}{l}\text { Clinical stage and grade and nodes invaded } \\
\text { Rhesus factor }\end{array}$ & $1.69(1 \cdot 17-2 \cdot 46)$ & 0.009 \\
\hline Rhesus factor & $1 \cdot 51(1 \cdot 08-2 \cdot 12)$ & 0.017 \\
\hline
\end{tabular}


with a relative risk of $1.56(95 \%$ confidence interval $1.08-2 \cdot 27)$ Finally, the effect of the four variables clinical stage, pathologica grade, nodal invasion, and blood group together was examined. Blood group again made a significant contribution $(p=0.009)$ with a relative risk of $1.69\left(95^{\circ}\right.$ o confidence interval $\left.1 \cdot 17-2 \cdot 46\right)$.

\section{Discussion}

If blood group is associated with survival from other diseases ${ }^{6}$ there would be some bias in the population towards older women. At the time of analysis, however, the only suitable information available on blood groups in the population was that from the Blood Transfusion Service, and a non-significant result was obtained when distributions were compared. In addition, the analysis was concerned with prognosis, not the risk of development of breast cancer.

In contrast with the results obtained in this series Donegan found a "good" relative survival in patients with blood group $\mathrm{AB}$, although figures for other blood groups were comparable. The exact reason for this difference is not clear as he did not discuss his findings in detail. We can only postulate possible causes such as differences in the distribution of blood groups in the population studied or different methods of selecting cases for the study.

By applying the log rank method and Cox's model we found that the type of blood group retained its significance and could be regarded as an independent factor of prognostic value, not explained by the presence of known clinical or pathological risk factors. We therefore believe that blood group should be considered in addition to these risk factors when a patient's prognosis is assessed.

We thank the following members of the Yorkshire Breast Cancer Group who participated in the study: Mr W G Harris, Mr E A Benson, Mr D S Hopton, Mr R Hall, Mr T S Matheson, Mr F G Smiddy, Mr W A F McAdam, Mr V S D Logan, Mr V K Modgill, Mr K Wilson, Mr G Wilson, Mr M Whittaker, Mr J J Price, Mr M Edwards, Professor C A Joslin, Dr D Ash, Dr S C Cartwright, Dr H G Frank, Dr R Cartwright, Dr A D Clayden, Dr P Cowen, Dr J Dossett, and Dr D Mackinnon.

\section{References}

1 Haybittle JL, Blamey RW, Elston CW, et al. A prognostic index in primary breast cancer. $B r \mathcal{F}$ Cancer 1982;45:361-6.

Donegan WL. Mastectomy in the primary management of invasive mammary

Kopec AC. The distribution of blood groups in the United Kingdom. London: Oxford University Press, 1979 .

Peto R, Pike MC, Armitage P, et al. Design and analysis of randomised clinical trials requiring prolonged observation of each patient. Br f Cancer 1977;35:1-39. ox DR. Regression models and life-tables. Fournal of the Royal Statistical Society, Series B 1972;34:187-220.

6 Hall R, Bunch GA, Humphrey CS. Arteriosclerosis, duodenal ulcer, blood group, and secretor status. $\mathrm{Br} M e d \mathcal{F} 1971 ;$ iii :767.

(Accepted 20 December 1984)
Patients with Wilson's disease, after initial "decoppering" with penicillamine or trientine dihydrochloride, require lifelong treatment, albeit at a reduced dose, to maintain their copper balance. Unfortunately, $5-10^{\circ}$ of patients develop intolerance to penicillamine, some of whom also develop intolerance to trientine dihydrochloride. I describe one such patient who was subsequently managed with unithiol (Dimaval; (2,3)-dimercaptopropane-(1)-sulphonate sodium salt). Other possible drugs are zinc salts (sulphate or acetate) ${ }^{2}$ and tetrathiomolybdate. ${ }^{3}$

\section{Case report}

A 13 year old boy presented with fluid retention. Biopsy showed cirrhosis of the liver. He was treated symptomatically. Three years later his younger sister died suddenly of liver failure; a genetic illness was suspected. A year later he developed dysarthria, and examination showed hepatosplenomegaly, gynaecomastia, and Kayser-Fleischer rings. His serum copper concentration was $4 \cdot 1 \mu \mathrm{mol} / 1(26 \mu \mathrm{g} / 100 \mathrm{ml})$ and urine copper excretion over $3 \cdot 1 \mu \mathrm{mol} / 24 \mathrm{~h}$ $(200 \mu \mathrm{g} / 24 \mathrm{~h})$. Penicillamine was started, and symptoms of the hepatic and the neurological disease rapidly cleared; after two years, however, he developed severe systemic lupus and a nephrotic syndrome. Penicillamine was stopped and prednisolone $5 \mathrm{mg}$ daily started.

The systemic lupus did not respond, and after two months he was referred to this hospital for possible treatment with trientine dihydrochloride. The prednisolone was increased to $60 \mathrm{mg}$ daily, which rapidly controlled the arthropathy and serositis but not the proteinuria. Trientine dihydrochloride was started, and he was discharged with instructions to reduce the dose of prednisolone slowly under local medical supervision. After two months, when he was taking prednisolone $5 \mathrm{mg}$ daily, the systemic lupus recurred. Trientine dihydrochloride was stopped and prednisolone increased to $10 \mathrm{mg}$ daily. For 15 months he remained well apart from heavy proteinuria. His serum copper concentration showed that his body stores of the metal were reaccumulating. Blood and urine copper concentrations had risen, and studies with radioactive copper showed that the liver was less efficient at sequestering copper and clearing the plasma of the radioisotope (table). ${ }^{4}$ He was therefore given a test dose of unithiol, an alternative chelating agent, which induced good cupruresis. A maintenance dose of $200 \mathrm{mg}$ twice daily was started. Copper excretion rose to $31 \cdot 5-47 \cdot 2 \mu \mathrm{mol}$ (2000$3000 \mu \mathrm{g}$ ) daily.

This treatment was continued, plus prednisolone $10 \mathrm{mg}$ daily, from February 1982, and, apart from heavy proteinuria, his health remained good. His blood and urine copper concentrations fell, though basal urine copper excretion was still higher than when penicillamine was stopped.

\section{Comment}

Although this particular water soluble analogue of dimercaprol has been used in Eastern Bloc countries for some time, it has not been available in western Europe, so little is known of its toxicity. One problem with the parent compound, dimercaprol, was the

Results of copper studies during treatment for Wilson's disease

\begin{tabular}{|c|c|c|c|c|c|c|c|}
\hline & \multirow[b]{2}{*}{ Treatment and its duration } & \multirow[b]{2}{*}{$\begin{array}{l}\text { Plasma copper } \\
(\mu \mathrm{mol} / 1)\end{array}$} & \multirow[b]{2}{*}{$\begin{array}{c}\text { Basal urine } \\
\text { copper } \\
(\mu \mathrm{mol} / 24 \mathrm{~h})\end{array}$} & \multicolumn{3}{|c|}{ Urine copper after: } & \multirow[b]{2}{*}{$\begin{array}{c}\text { Radioactive } \\
\text { copper (plasma } \\
24 \mathrm{~h}: 2 \mathrm{~h} \text { ratio) }\end{array}$} \\
\hline & & & & $\begin{array}{c}\text { Penicillamine } \\
(\mu \mathrm{mol} / 24 \mathrm{~h})\end{array}$ & $\begin{array}{c}\text { Trientine } \\
\text { dihydrochloride } \\
(\mu \mathrm{mol} / 6 \mathrm{~h})\end{array}$ & $\begin{array}{c}\text { Unithiol } \\
(\mu \mathrm{mol} / 6 \mathrm{~h})\end{array}$ & \\
\hline $\begin{array}{l}\text { July } 1977 \\
\text { November } 1979 \\
\text { November } 1980 \\
\text { March } 1982 \\
\text { February } 1983 \\
\text { March } 1984\end{array}$ & $\begin{array}{l}\text { Nil } \\
\text { Penicillamine, } 2 \text { years } \\
\text { Trientine dihydrochloride, } 1 \text { year } \\
\text { Nil, } 15 \text { months } \\
\text { Unithiol, } 1 \text { year } \\
\text { Unithiol, } 2 \text { years }\end{array}$ & $\begin{array}{l}4 \cdot 1 \\
0.9 \\
0 \cdot 8 \\
6 \cdot 8 \\
1.9 \\
1 \cdot 7\end{array}$ & $\begin{array}{r}3 \cdot 1 \\
0.6 \\
0 \cdot 6 \\
12 \cdot 1 \\
2.5 \\
1 \cdot 7\end{array}$ & $21 \cdot 9$ & $\begin{array}{r}2.1 \\
1.5 \\
40.7 \\
2.9\end{array}$ & $\begin{array}{r}20 \cdot 7 \\
3 \cdot 1 \\
2 \cdot 4\end{array}$ & $\begin{array}{l}0 \cdot 15 \\
0 \cdot 29\end{array}$ \\
\hline
\end{tabular}

